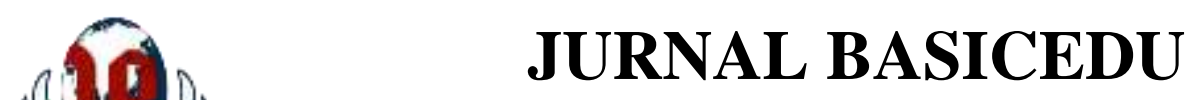

Volume 5 Nomor 6 Tahun 2021 Halaman 5802 - 5809

Research \& Learning in Elementary Education

https://jbasic.org/index.php/basicedu

\title{
Implementasi Pembelajaran Berbasis Praktikum Terhadap Hasil Belajar Siswa dalam Materi Arthropoda di SMP
}

\author{
Gunaria Siagian $^{凶}$ \\ Universitas HKBP Nommensen Pematangsiantar, Indonesia \\ E-mail: gunariasiagian5@gmail.com
}

\begin{abstract}
Abstrak
Permasalahan dalam penelitian ini adalah tenatang kajian implementasi pembelajaran berbasis praktikum untuk meningkatkan hasil belajar siswa dalam materi arthropoda di SMP Methodist Pematangsiantar. Tujuan dari penelitian ini adalah untuk mengetahui perbedaan hasil belajar siswa yang diberikan metode praktikum dengan siswa yang mengikuti pembelajaran materi arthropoda dengan metode konvensional (ceramah). Penelitian ini dilaksanakan di SMP Methodist Pematangsiantar. Pengambilan sampel dipilih berdasarkan populasi terjangkau sebanyak dua kelas yaitu kelas VII-A dan VII-B SMP Methodist Pematangsiantar. Teknik pengambilan sampel digunakan dengan cara "simple random sampling", sebanyak 20 orang peserta didik dari 36 peserta didik di kelas VII-A sebagai kelas yang diajar dengan menggunakan media praktikum, sedangkan pada kelas kontrol diambil sebanyak 20 orang peserta didik dari 37 peserta didik di kelas VII-B menggunakan metode konvensional. Penelitian ini dilaksanakan mulai Januari 2021 sampai Februari 2021. Nilai rata-rata hasil belajar peserta didik yang diajarkan dengan Praktikum lebih tinggi, yaitu 74,76 sehingga terdapat perbedaan nilai rata-rata hasil belajar dengan selisih 6,76. Kemudian dari hasil pengujian hipotesis yang dilakukan dengan uji t diketahui bahwa Thitung $(2,65)>$ Ttabel $(2,03)$ yang artinya terdapat perbedaan yang signifikan antara hasil belajar peserta didik kelas eksperimen dan kelas kontrol. Oleh karena itu dapat disimpulkan bahwa terdapat pengaruh Praktikum terhadap hasil materi Arthropoda peserta didik SMP Methodist Pematangsiantar.
\end{abstract}

Kata Kunci: Praktikum, Arthropoda

\begin{abstract}
The problem in this research is the study of the implementation of practicum-based learning to improve student learning outcomes in arthropod material at Pematangsiantar Methodist Middle School. The purpose of this research is to find out the differences in learning outcomes of students who are given a practicum method with students who follow learning material arthropods with conventional methods (lectures). This research was conducted at SMP Methodist Pematangsiantar. Sampling was selected based on an affordable population of two classes, namely class VII-A and VII-B SMP Methodist Pematangsiantar. The sampling technique was used by "simple random sampling", as many as 20 students from 36 students in class VII-A as a class taught using practicum media, while in the control class 20 students were taken from 37 students in the class. VII-B using the conventional method. This research was conducted from January 2021 to February 2021. The average value of student learning outcomes taught by practicum is higher, namely 74.76 so that there is a difference in the average value of learning outcomes with a difference of 6.76. Then from the results of hypothesis testing conducted with the t test, it is known that Tcount (2.65) > Ttable (2.03), which means that there is a significant difference between the learning outcomes of the experimental class and control class students. Therefore, it can be concluded that there is an effect of practicum on the material results of Arthropoda students of Pematangsiantar Methodist Junior High School.
\end{abstract}

Keywords: Practicum, Arthropod

Copyright (c) 2021 Gunaria Siagian

Corresponding author :

Email: gunariasiagian5@gmail.com

DOI : https://doi.org/10.31004/basicedu.v5i6.1498

ISSN 2580-3735 (Media Cetak)

ISSN 2580-1147 (Media Online)

Jurnal Basicedu Vol 5 No 6 Tahun 2021

p-ISSN 2580-3735 e-ISSN 2580-1147 
5803 Implementasi Pembelajaran Berbasis Praktikum Terhadap Hasil Belajar Siswa dalam Materi Arthropoda di SMP - Gunaria Siagian

DOI: https://doi.org/10.31004/basicedu.v5i6.1498

\section{PENDAHULUAN}

Proses belajar mengajar biologi dilaksanakan tidak hanya dapat dilakukan di dalam kelas. Ciri dari pembelajaran biologi adalah adanya kegiatan praktikum baik di laboratorium maupun di alam. Banyak konsep biologi yang kompleks sehingga diperlukan suatu kegiatan untuk memudahkan siswa dalam memahami konsep tersebut. Kegiatan praktikum sangat sesuai untuk memfasilitasi siswa belajar melalui pengalaman langsung. Praktikum memberikan kesempatan kepada siswa untuk mendapatkan gambaran dalam keadaan yang nyata tentang apa yang diperoleh dalam teori dan terjadi kontak indera. Selain itu, dalam kegiatan praktikum siswa tidak sekedar mengamati secara langsung tetapi dapat menghayati, terlibat langsung dalam perbuatan dan bertanggung jawab terhadap hasilnya. Untuk itu perlu dilakukan pembelajaran berbasis praktikum yang di dalamnya memuat sejumlah pertanyaan untuk menggiring siswa melaksanakan kegiatan praktikum dan menemukan konsep pembelajaran yang dipelajari (Hong, J.C Tsai, C.R Hasio, H.S.,Chen,P.H., 2019). Buner (Trianto, 2009) juga mengemukakan bahwa belajar penemuan sesuai dengan pencarian pengetahuan secara aktif oleh manusia, dan dengan sendirinya memberi hasil yang paling baik.

Proses pembelajaran pada setiap satuan pendidikan dasar dan menengah harus interaktif, inspiratif, menyenangkan, menantang, dan memotivasi peserta didik untuk berpartisipasi aktif, serta memberikan ruang yang cukup bagi prakarsa, kreativitas, dan kemandirian sesuai dengan bakat, minat, dan perkembangan fisik serta psikologis peserta didik (Hsu, Y. S., Wang, C.Y., \& Zhang, 2017) (Candra O, Pulungan, A. B., Eliza, F ., Elfizon, \& Syamsuarniis, 2019). Peserta didik diharapkan tidak hanya menguasai konsep tetapi juga memiliki keterampilan dalam melakukan kegiatan praktikum (Yanto, D.T.P.,Astrid, E.,Hidayat R., 2019). Menurut Rustaman (2003) dalam Purwaningsih (2014) (Purwaningsih, 2014) secara garis besar praktikum sering dikaitkan dengan beberapa tujuan: memotivasi siswa/mahasiswa sebab kegiatan praktikum pada umumnya menarik siswa/mahasiswa sehingga mereka termotivasi untuk belajar sains, mengajarkan keterampilan dasar ilmiah, meningkatkan pemahaman konsep, memahami dan menggunakan metode ilmiah, dan mengembangkan sikap ilmiah. Dengan melakukan praktikum mahasiswa akan termotivasi, terampil dan mudah dalam memahami konsep dalam pembelajaran sains.

(A.M., 2012), (Dahar, 2011), (Uno, 2006), (Hamalik, 2005) dan (Sudjana, 2005) mengemukakan bahwa "belajar itu senantiasa merupakan perubahan tingkah laku atau penampilan, dengan serangkaian kegiatan misalnya dengan membaca, mengamati, mendengarkan, meniru dan lain sebagainya". Akan tetapi, menurut (Sudjana, 2005) "diantara ranah bidang kognitif, afektif, dan psikomotor, ranah kognitiflah yang paling banyak dinilai oleh para guru karena berkaitan dengan kemampuan para siswa dalam menguasai isi dan bahan pengajaran". Menurut (Slameto, 2013) faktor-faktor yang mempengaruhi hasil belajar yaitu faktor intern dan ekstren, salah satunya faktor psikologis. Faktor Psikologis adalah ilmu yang mempelajari tentang kejiwaan, baik mengenai macam-macamnya, maupun latar belakangnya (Ahmadi, lif Khoiru, 2011).

Metode praktikum adalah cara penyajian pelajaran dengan menggunakan percobaan. Dalam pelaksanaan metode ini siswa melakukan kegiatan yang mencakup pengendalian variabel, pengamatan, melibatkan pembanding atau kontrol, dan penggunaan alat-alat praktikum. Praktikum memegang peranan penting dalam pendidikan sains, karena dapat memberikan latihan metode ilmiah kepada siswa dengan mengikuti petunjuk yang telah diperinci dalam lembar petunjuk. Dengan melakukan praktikum siswa juga akan menjadi lebih yakin atas satu hal daripada hanya menerima dari guru dan buku, dapat memperkaya pengalaman, mengembangkan sikap ilmiah, dan hasil belajar akan bertahan lebih lama dalam ingatan siswa (Rustaman, 2011). Terkait dengan uraian diatas, maka guru dituntut untuk lebih inovatif dan kreatif menggunakan berbagai metode pembelajaran untuk memfasilitasi siswa dalam proses pembelajaran, dan meninggalkan metode konvensional atau metode ceramah. Metode ceramah adalah metode yang boleh dikatakan tradisional karena sejak dulu metode ini telah digunakan sebagai alat komunikasi lisan antara guru dengan anak didik dalam proses belajar dan mengajar (Djamariah, 2006). Menurut (Kemendikbud, 2016) beberapa kompetensi yang harus dicapai siswa dalam 
pelajaran Biologi yaitu menerapkan proses kerja ilmiah dan keselamatan kerja di laboratorium Biologi maupun di luar laboratorium dalam pengamatan dan percobaan untuk memahami permasalahan biologi pada berbagai objek, mengkomunikasikan hasil pengamatan dan percobaan secara lisan maupun tulisan, menyajikan data berbagai objek berdasarkan pengamatan dan percobaan dengan menerapkan prosedur ilmiah.

Jadi, ukuran cocok tidaknya suatu media sangatlah sederhana, yakni jika metode tersebut dapat memberikan hasil memuaskan seperti tujuan yang hendak dicapai, maka metode tersebut cocok untuk digunakan. Maka masalah yang akan diteliti yaitu Adakah pengaruh penerapan metode pembelajaran berbasis praktikum untuk meningkatkan motivasi dan hasil belajar biologi materi Arthropoda di SMP Methodist Pematangsiantar.

\section{METODE PENELITIAN}

Penelitian ini dilaksanakan di SMP Methodist Pematangsiantar tempat Pengambilan sampel dipilih berdasarkan populasi terjangkau yaitu sebanyak dua kelas yaitu kelas VII-A an VII-B SMP Methodist Pematangsiantar. Dalam pengambilan data, peneliti mengambil teknik sampling "simple random sampling", sebanyak 20 orang peserta didik dari 36 peserta didik di kelas VII-A sebagai kelas yang diajar dengan menggunakan media praktikum, sedangkan pada kelas kontrol diambil sebanyak 20 orang peserta didik dari 37 peserta didik di kelas VII-B menggunakan metode konvensional. Penelitian ini akan dilaksanakan mulai Januari 2021 sampai Februari 2021.

Populasi seluruh objek dalam batas tertentu yang akan dilakukan peneliti terhadap ciri masing individu (Sahroni, 1986). Sampel adalah bagian dari jumlah dan karakteristik yang dimiliki oleh populasi tersebut (Sugiyono, 2013). Pengambilan sampel dipilih berdasarkan populasi terjangkau yaitu sebanyak dua kelas yaitu kelas VII-A dan VII-B SMP Methodist Pematangsiantar. Dalam pengambilan data, peneliti mengambil teknik sampling "simple random sampling" Dalam penelitian ini memerlukan satu macam data pokok dari variabel terikat. Untuk mengetahui data pokok tersebut digunakan instrumen. Instrumen yang digunakan dalam penelitian ini adalah tes objektif pilihan ganda dengan 5 alternatif jawaban dan 2 tes non objektif essay.

Instrumen yang digunakan dalam penelitian ini adalah tes objektif pilihan ganda dengan 4 alternatif jawaban. Tes ini digunakan untuk mengukur tingkat keberhasilan peserta didik dalam materi Arthropoda. Data yang diperoleh dari penelitian ini berupa data kuantitatif. Data kuantitatif merupakan suatu data yang berkenaan dengan hasil belajar peserta didik yang diukur melalui instrumen soal berupa pilihan ganda dan essay. Jumlah seluruh soal adalah 17 butir. Analisis deskriptif yang dilakukan bermaksud untuk mengujikan data yang ditampilkan dalam bentuk rerata (mean), nilai tengah (median), variasi terbanyak yang didapat (modus), simpanganx baku, rentang skor, distribusi frekuensi yang juga digambarkan dalam bentuk grafik dan prosedur analisis data.

Dalam pengambilan data, peneliti mengambil teknik sampling "simple random sampling". Variabel ditetapkan oleh peneliti untuk dipelajari sehingga diperoleh informasi tentang hal tersebut, kemudian ditarik kesimpulannya (Sugiyono, 2013). Adapun variabel yang digunakan dalam penelitian ini, terdiri atas 2 variabel, yaitu:

1. Variabel bebas $(X)$, yaitu metode pembelajaran, meliputi metode praktikum dan konvensional (ceramah)

2. Variabel terikat $(Y)$, yaitu hasil belajar.

\section{HASIL DAN PEMBAHASAN}

Data kelompok kontrol adalah kelas yang tidak diberi perlakuan Praktikum yaitu kelas VII.B. Data distribusi frekuensi tersebut dapat disajikan dalam bentuk poligon dan histogram yang dapat dilihat dalam gambar berikut ini: 


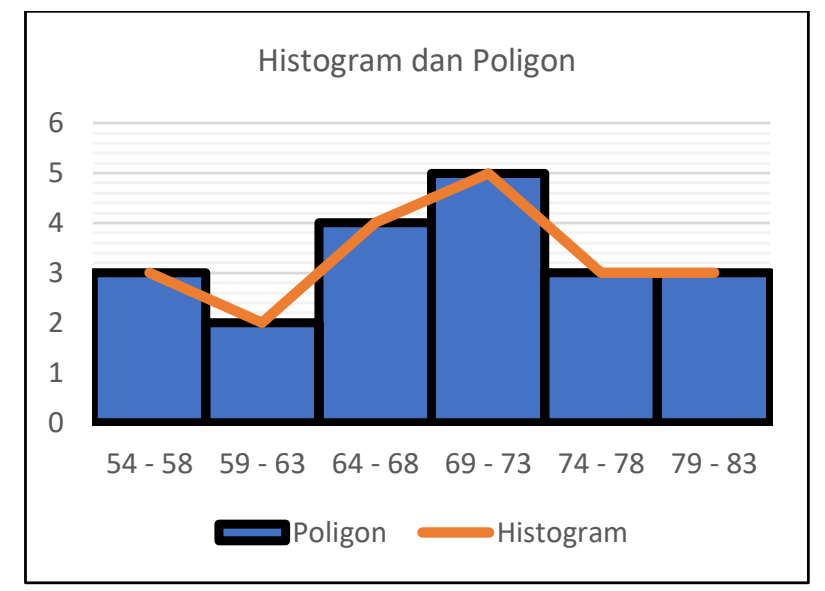

\section{Gambar 1. Histogram dan Poligon Hasil Belajar Peserta Didik Kelompok Kontrol}

Berdasarkan pada gambar maka dapat disimpulkan bahwa nilai tertinggi berada pada interval kelas 79 83 sebanyak tiga orang peserta didik, sedangkan nilai terendah berada interval kelas 59-63 sebanyak dua orang peserta didik. Sementara untuk nilai dengan nilai terbanyak berada pada interval $69-73$ sebanyak lima orang peserta didik. Dengan demikian, dapat disimpulkan bahwa rata-rata skor kelas kontrol sebesar 69, median sebesar 69,5, modus sebesar 70,16 dan simpangan baku sebesar 9,17.

\section{Kelompok Eksperimen}

Kelompok eksperimen adalah kelas yang diberikan perlakuan Praktikum, yaitu kelas IX A. Setelah melalui proses pengolahan data distribusi frekuensi. Data distribusi frekuensi tersebut dapat disajikan dalam bentuk poligon dan histogram yang dapat dilihat dalam gambar berikut ini:

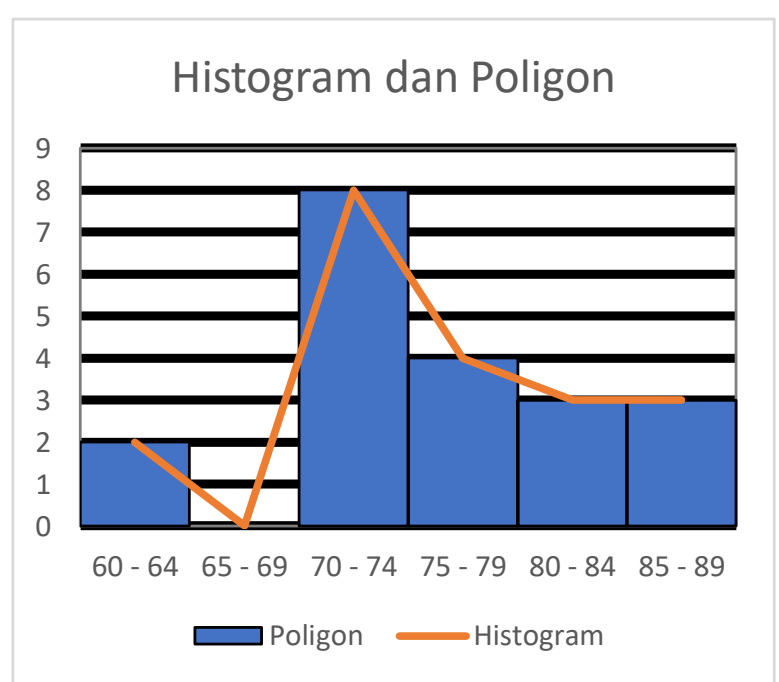

\section{Gambar 2. Histogram dan Poligon Hasil Belajar Peserta Didik Kelompok Eksperimen}

Berdasarkan pada gambar maka dapat disimpulkan bahwa 3 orang peserta didik nilai tertinggi berada pada interval kelas 85 - 89, sedangkan nilai terendah sebanyak 2 orang peserta didik berada interval kelas 60 64. Sementara untuk nilai dengan nilai terbanyak berada pada interval $70-74$ sebanyak 8 orang peserta didik. Dengan demikian, dapat disimpulkan bahwa rata-rata skor kelas kontrol sebesar 75, median sebesar 74,6, modus sebesar 72,84 dan simpangan baku sebesar 8,24.

Uji normalitas data dilakukan untuk dapat mengetahui data hasil penelitian berdistribusi normal atau tidak, maka penelitian harus diuji penelitiannya. Dalam penelitian ini, peneliti menggunakan perhitungan uji Liliefors. Uji normalitas dengan Liliefors dipergunakan untuk menguji data dalam bentuk data tunggal dalam tabel distribusi frekuensi. 
DOI: https://doi.org/10.31004/basicedu.v5i6.1498

\section{Uji Normalitas Kelas Kontrol}

Tabel 1

Uji Normalitas Kelompok Kontrol

\begin{tabular}{ccccccccc}
\hline Skor & $\mathbf{f}$ & $\mathbf{f}_{\mathbf{k}}$ & $\mathbf{Z}_{\mathbf{i}}$ & $\mathbf{X}_{\mathbf{i}}$ & $\mathbf{F}(\mathbf{Z i})$ & $\mathbf{S}(\mathbf{z i})$ & $\mathbf{F}(\mathbf{z i})-\mathbf{S}(\mathbf{z i})$ & {$[\mathbf{F}(\mathbf{z i})-\mathbf{S}(\mathbf{z i})]$} \\
\hline 54 & 2 & 2 & $-1,83$ & 0,4657 & 0,0345 & 0,1 & $-0,0657$ & 0,0657 \\
56 & 1 & 3 & $-1,47$ & 0,4280 & 0,0722 & 0,16 & $-0,0780$ & 0,0780 \\
62 & 2 & 5 & $-0,77$ & 0,2765 & 0,2237 & 0,26 & $-0,0265$ & 0,0265 \\
66 & 4 & 9 & $-0,29$ & 0,1104 & 0,3898 & 0,46 & $-0,0604$ & 0,0604 \\
69 & 3 & 12 & 0,07 & 0,0240 & 0,5240 & 0,6 & $-0,0762$ & 0,0762 \\
72 & 2 & 14 & 0,42 & 0,1592 & 0,6592 & 0,7 & $-0,0410$ & 0,0410 \\
75 & 3 & 17 & 0,78 & 0,2795 & 0,7795 & 0,86 & $-0,0707$ & 0,0707 \\
82 & 3 & 20 & 1,58 & 0,4293 & 0,9293 & 1 & $-0,0709$ & 0,0709 \\
$\Sigma$ & $\mathbf{2 0}$ & & & & & & & $\mathbf{L o = 0 , 0 7 8 0}$ \\
\hline
\end{tabular}

Berdasarkan Tabel, terlihat bahwa hasil penelitian diperoleh Lo sebesar 0,0780, sedangkan $L_{\text {tabel }}$ berdasarkan tabel Lilifors untuk $\mathrm{n}=20$ dan $\alpha=5 \%$, maka dapat diketahui nilai $L_{\text {tabel }}$ adalah sebesar 0,190 . Dengan demikian, dapat disimpulkan bahwa $L_{\text {hitung }}<L_{\text {tabel }}(0,0780<0,190)$ hal ini berarti sampel berdistribusi normal.

\section{Uji Normalitas Kelas Eksperimen}

Tabel 2

Uji Normalitas Kelompok Eksperimen

\begin{tabular}{ccccccccc}
\hline Skor & $\mathbf{f}$ & $\mathbf{f}_{\mathbf{k}}$ & $\mathbf{Z}_{\mathbf{i}}$ & $\mathbf{X}_{\mathbf{i}}$ & $\mathbf{F}(\mathbf{Z i})$ & $\mathbf{S}(\mathbf{z i})$ & $\mathbf{F}(\mathbf{z i})-\mathbf{S}(\mathbf{z i})$ & {$[\mathbf{F}(\mathbf{z i})-\mathbf{S}(\mathbf{z i})]$} \\
\hline 60 & 2 & 2 & $-2,006$ & 0,4803 & 0,0198 & 0,1 & $-0,0804$ & 0,0804 \\
69 & 3 & 5 & $-0,686$ & 0,2517 & 0,2484 & 0,25 & $-0,0018$ & 0,0018 \\
72 & 5 & 10 & $-0,29$ & 0,1141 & 0,3860 & 0,5 & $-0,1142$ & 0,1142 \\
75 & 4 & 14 & 0,1056 & 0,0398 & 0,5399 & 0,7 & $-0,1603$ & 0,1603 \\
81 & 3 & 17 & 0,8973 & 0,3133 & 0,8134 & 0,85 & $-0,0368$ & 0,0368 \\
85 & 2 & 19 & 1,2932 & 0,4015 & 0,9016 & 0,95 & $-0,0486$ & 0,0486 \\
89 & 1 & 20 & 1,821 & 0,4656 & 0,9657 & 1 & $-0,0345$ & 0,0345 \\
$\Sigma$ & $\mathbf{2 0}$ & & & & & & & $\mathbf{L o = 0 , 1 6 1 3}$ \\
\hline
\end{tabular}

Berdasarkan Tabel, terlihat bahwa hasil penelitian diperoleh Lo sebesar 0,1613 , sedangkan $L_{\text {tabel }}$ berdasarkan tabel Lilifors untuk $\mathrm{n}=20$ dan $\alpha=5 \%$, maka dapat diketahui nilai $L_{\text {tabel }}$ adalah sebesar 0,190 . Dengan demikian, dapat disimpulkan bahwa $L_{\text {hitung }}<L_{\text {tabel }}(0,1613<0,190)$ hal ini berarti sampel berdistribusi normal.

Pada Uji Homogenitas Persyaratan uji statistik inferensial parametik yang kedua adalah homogenitas data. Pengujian homogenitas data adalah pengujian sama tidaknya variansi-variansi dua buah atau lebih. Pengujian homogenitas data menggunakan perhitungan uji Fisher dengan rumus sebagai berikut:

$$
\mathrm{F}_{\text {hitung }}=\frac{\text { varianterbesar }}{\text { varianterkecil }}
$$

Berdasarkan tabel data uji normalitas, didapat nilai ragam untuk data kelompok kontrol $S_{1}^{2}$ sebesar 66,7490, sedangkan nilai ragam untuk kelompok eksperimen $S_{2}^{2}$ sebesar 52,2730. Selanjutnya dilakukan perhitungan uji Fisher, Berdasarkan perhitungan uji Fisher di atas, didapat nilai $F_{h i t u n g}=1,276932$. Setelah memperoleh nilai $\mathrm{F}_{\text {hitung, }}$, selanjutnya membandingkan dengan nilai tabel distribusi $F$. Besar nilai $\mathrm{F}_{\text {tabel }}$ untuk $\alpha$ $=0,05$ dengan $d k=\mathrm{n}_{1}-1, \mathrm{n}_{2}-1=20-1=19,20-1=19$. Jika nilai tabel tidak ada, dan hanya ada nilai $\mathrm{t}_{\text {tabel }}$ untuk $d k=16$ dan $d k=20$, penetuan nilai tabel untuk $d k=$ dilakukan dengan cara interpolasi. Dengan menggunakan rumus sebagai berikut:

$$
C=C_{0}+\frac{\left(C_{1}-C_{0}\right)}{\left(B_{1}-B_{0}\right)}\left(B-B_{0}\right)
$$


5807 Implementasi Pembelajaran Berbasis Praktikum Terhadap Hasil Belajar Siswa dalam Materi Arthropoda di SMP - Gunaria Siagian

DOI: https://doi.org/10.31004/basicedu.v5i6.1498

Berdasarkan perhitungan interpolasi diatas, dapat diketahui bahwa nilai $F_{\text {tabel }}=2,165$. Setelah dibandingkan dapat diketahui bahwa 1,276932 <2,165 atau $\mathrm{F}_{\text {hitung }}<\mathrm{F}_{\text {tabel. }}$ Sehingga dapat disimpulkan kedua sampel dikatakan homogen. Hasil perhitungan uji normalitas menunjukkan bahwa data berasal dari populasi yang terdistribusi normal sedangkan uji homogenitas menunjukan bahwa kedua data dapat dikatakan homogen. Hal ini membuktikan bahwa data layak digunakan untuk uji hipotesis.

Pengujian Hipotesis Penelitian ini atau Analisis data dalam penelitian ini dilakukan dengan cara, membandingkan data dua kelompok sampel, atau dengan membandingkan data antara kelompok eksperimen dengan kelompok kontrol, atau membandingkan peningkatan data kelompok eksperimen dengan data kelompok kontrol, maka dilakukan pengujian dengan uji-t sebagai berikut:

Kriteria pengujian hipotesis:

$$
\begin{aligned}
& \mathrm{H}_{0}: \mu_{\mathrm{B}}=\mu_{\mathrm{B}} \\
& \mathrm{H}_{1}: \mu_{\mathrm{A}} \neq \mu_{\mathrm{B}}
\end{aligned}
$$

Langkah pertama ialah dengan menentukan besar nilai sgab dengan rumus sebagai berikut:

$$
\begin{aligned}
S_{\text {gab }} & =\sqrt{\frac{\left(n_{A}-1\right) S_{A}^{2}+\left(n_{B}-1\right) S_{B}^{2}}{n_{A}+n_{B}-2}} \\
S_{\text {gab }} & =8,042894906
\end{aligned}
$$

Selanjutnya dapat menghitung nilai t dengan rumus:

$$
\begin{aligned}
& \mathrm{t}=\frac{\bar{X}_{A-\bar{X}_{B}}}{\mathrm{~s}_{\text {gab }} \sqrt{\frac{1}{n_{A}}}+\frac{1}{n_{B}}} \\
& \mathrm{t}=2,657480316
\end{aligned}
$$

Berdasarkan perhitungan uji $\mathrm{t}$ di atas, didapat nilai $\mathrm{t}_{\text {hitung }}=2,657480316$ setelah didapatkan nilaai dari $\mathrm{t}_{\text {hitung, }}$, selanjutnya dibandingkan dengan nilai tabel dari tabel distribusi t. Besar nilai $\mathrm{t}_{\text {tabel }} \alpha=0,05$ dengan $d k=$ $\mathrm{n}_{1}+\mathrm{n}_{2}-2=20+20-2=38$. Jika nilai $\mathrm{t}_{\text {tabel }}$ tidak ada, dan hanya ada nilai $\mathrm{t}_{\text {tabel }}$ untuk $d k=30$ dan $d k=40$, penetuan nilai $\mathrm{t}_{\text {tabel }}$ untuk $d k=38$ dilakukan dengan cara interpolasi. Dengan menggunakan rumus sebagai berikut:

$$
\begin{aligned}
& C=C_{0}+\frac{\left(C_{1}-C_{0}\right)}{\left(B_{1}-B_{0}\right)}\left(B-B_{0}\right) \\
& C=2,0253
\end{aligned}
$$

\section{Keterangan:}

C0 $\quad$ : Nilai distribusi $\mathrm{t}=30$

C1 : Nilai distribusi $\mathrm{t}=40$

B $\quad: \mathrm{dk}=\mathrm{nA}+\mathrm{nB}-2=40-2=38$

B0 : Nomorurut pada distribusi t sebelum No. 38

B1 : Nomorurut pada distribusi t setelah No. 40

Berdasarkan perhitungan interpolasi di atas, sehingga dapat diketahui nilai $\mathrm{t}_{\text {tabel }}$ untuk $\alpha=0,05 \mathrm{dan} \mathrm{dk}=$ 38 yaitu $t_{\text {tabel }}=2,0253=2,03$. Selanjutnya membandingkan nilai $t_{\text {hitung }}$ dengan nilai $t_{\text {tabel }}$. Karena 2,657480316 $>2,0253$ atau $t_{\text {hitung }}>t_{\text {tabel }}$ maka $\mathrm{H}_{0}$ ditolak yang artinya pada tingkat kepercayaan $95 \%$ nilai akhir pesertadidik yang menggunakan praktikum lebih tinggi secara signifikan dari pada peserta didik yang menggunakan model konvensional pada pembelajaran Arthropoda.

Dari hasil penelitian dapat diketahui hasil belajar dari kelas eksperimen dengan skor rata-rata 74,76, median 73,6, modus 71,84, simpangan baku 7,24 dan $L_{0} 0,163$, sedangkan hasil belajar dari kelas kontrol dengan skor rata-rata 68, median 68,6, modus 69,17, simpangan baku 8,18 dan $L_{0} 0,07$. Dari hasil perhitungan dapat diketahui bahwa skor rata-rata kelas eksperimen lebih tinggi dari pada kelas kontrol dengan selisih 6,76 dengan data masing-masing kelas berdistribusi normal dan dari hasil perhitungan uji homogenitas dapat diketahui $f_{\text {hitung }}$ 
1,27. Oleh karena itu, kedua data mempunyai varian yang homogen. Setelah diketahui dari hasil perhitungan bahwa skor rata-rata eksperimen lebih tinggi dibandingkan skor rata-rata kelas kontrol, kemudian diperkuat lagi dengan pengujian hipotesis menggunakan uji- $t$ yang diketahui hasil $t_{\text {hitung }}$ sebesar 2,65. Dengan demikian, dapat disimpulkan bahw $H_{0}$ ditolak yang berarti hasil belajar dengan menggunakan praktikum lebih efektif dibandingkan dengan model pembelajaran Konvensional. Selain menggunakan media praktikum, (Siagian, 2020) menyatakan bahwa pembelajaran menggunakan Media Instructional Content juga lebih efektif dari model pembelajaran konvensional.

Dari hasil perolehan data dapat diketahui bahwa Praktikum mempunyai hasil belajar lebih tinggi dibandingkan model pembelajaran Konvensional, karena Praktikum memiliki kelebihan-kelebihan. Dalam proses pembelajaran peserta didik dituntut untuk aktif, kreatif dan cepat tanggap. Strategi ini membuat peserta didik menjadi siap untuk memulai pelajaran, karena peserta didik belajar terlebih dahulu sehingga memiliki sedikit gambaran tentang materi yang akan disampaikan dan menjadi lebih paham setelah mendapat tambahan penjelasan dari guru. Adapun dengan model pembelajaran konvensional, model ini mempunyai hasil belajar yang lebih rendah dibandingkan dengan Praktikum. Hal ini dikarenakan dalam pembelajaran yang menggunakan konvensional, peserta didik hanya mendengarkan dan memperhatikan materi pelajaran yang disampaikan oleh guru, sehingga peserta didik menjadi membosankan dan kurang menarik, serta menghasilkan pembelajaran yang pasif. Hal ini sesuai dengan pendapat (Situmorang, 2020) sebagai hasil akhir pembelajaran non konvensional, siswa memiliki skill untuk mengingat kembali bahkan mampu menyampaikan kembali informasi yag telah diperoleh sebelumnya secara cepat dan tepat. Pembelajaran berbasis praktikum menjadi strategi pembelajaran yang baik bagi mahasiswa untuk mengembangkan keterampilan manipulatif, keterampilan hands on dan mind on, karena mahasiswa ditantang untuk aktif dalam memecahkan masalah, berpikir kritis dan kreatif dalam mengungkap fakta, membangun konsep, dan menerapkan prinsip-prinsip agar menjadi lebih bermakna (Sukaesih, S., 2011). (Sugiyono, 2013) juga mengemukakan empat alasan mengenai kegiatan praktikum yaitu Praktikum membangkitkan motivasi belajar, mengembangkan keterampilan eksperimen, menjadi wahana belajar pendekatan ilmiah, penunjang materi pembelajaran.

Berdasarkan penjelasan statistik dan teoritik, menunjukan bahwa terdapat perbedaan yang signifikan antara hasil belajar materi Arthropoda yang diajarkan dengan menggunakan Praktikum dengan hasil belajar materi Arthropoda, yang diajarkan dengan menggunakan model pembelajaran konvensional pada pokok bahasan Arthropoda. Dengan demikian, dapat disimpulkan bahwa terdapat pengaruh Praktikum terhadap hasil belajar materi Arthropoda.

\section{KESIMPULAN}

Dari hasil penelitian maka disimpulkan bahwa terdapat pengaruh hasil belajar pada pokok bahasan Arthropoda di SMP Methodist Pematangsiantar, yang diajarkan dengan menggunakan model pembelajaran Konvensional mempunyai nilai rata-rata 68, sedangkan nilai rata-rata hasil belajar peserta didik yang diajarkan dengan Praktikum lebih tinggi, yaitu 74,76 sehingga terdapat perbedaan nilai rata-rata hasil belajar dengan selisih 6,76. Kemudian dari hasil pengujian hipotesis yang dilakukan dengan uji t diketahui bahwa $\mathrm{T}_{\text {hitung }}(2,65)$ $>\mathrm{T}_{\text {tabel }}(2,03)$ yang artinya terdapat perbedaan yang signifikan antara hasil belajar peserta didik kelas eksperimen dan kelas kontrol. Oleh karena itu dapat disimpulkan bahwa terdapat pengaruh Praktikum terhadap hasil materi Arthropoda peserta didik SMP Methodist Pematangsiantar.

\section{UCAPAN TERIMA KASIH}

Terimakasih kepada Bapak/Ibu guru SMP Methodist Pematangsiantar, yang telah banyak membantu selama proses penelitian ini berlangsung. 
5809 Implementasi Pembelajaran Berbasis Praktikum Terhadap Hasil Belajar Siswa dalam Materi Arthropoda di SMP - Gunaria Siagian

DOI: https://doi.org/10.31004/basicedu.v5i6.1498

\section{DAFTAR PUSTAKA}

A.M., S. (2012). Interaksi \& Motivasi Belajar Mengajar. Rajagrafindo Persada.

Ahmadi, Iif Khoiru, D. (2011). Strategi Pembelajaran Sekolah Terpadu. PT. Prestasi Putakaraya.

Candra O, Pulungan, A. B., Eliza, F ., Elfizon, \& Syamsuarniis, (2019). (2019). Development of Miniature Secondary Network of Electric Power Distribution System as a Learning Media for Electrical Engineering Students. Journal of Physics: Conference Series, 1165, 1, 1165.

Dahar, R. W. (2011). Teori-Teori Belajar dan Pembelajaran. Erlangga.

Djamariah, S. B. dan A. Z. (2006). Strategi Belajar Mengajar edisi revisi.

Hamalik, O. (2005). Proses Belajar Mengajar. PT. Bumi Aksara.

Hong,J.C Tsai, C.R Hasio, H.S.,Chen,P.H. (2019). The effect of the "Prediction-observation-quiz explanation"inquiry-based e-learning model on flow experience in green energy learning. Computers and Education. Computer and Education, 127-138.

Hsu, Y. S., Wang, C.Y., \& Zhang, W. . (2017). Supporting technology-enhanced inquary throught metacognitive and cognitive prompts. Computers in Human Behavior, 701-712.

Kemendikbud, T. (2016). Permendiknas. 21.

Purwaningsih, y. I. (2014). Pengembangan Petunjuk Praktikum Biologi Ilustratif Berbasis Pendekatan Inkuiri Terbimbing (guanded inkuiri) yang Mengembangkan Pendidikan Karakter pada Materi Pokok SIstem Pencernaan Makanan untuk Kelas XI Semester 1 di SMA Muhamadiyah3 Yogyakarta.

Rustaman, N. (2011). Strategi Belajar Mengajar Biologi. Universitas Negeri Malang.

Sahroni. (1986). Pengelolaan Pembelajaran Biologi. Universitas Terbuka.

Siagian, G. (2020). Prosiding Seminar Nasional Sains Pengaruh Media Instructional Content Terhadap Hasil Belajar IPA X1. 1(1), 301-309.

Situmorang, M. (2020). Pengaruh Peta Pikiran dalam Tatanan Pembelajaran terhadap Hasil Belajar Siswa. Jurnal Pendidikan MIPA, 10.

Slameto. (2013). Belajar dan Faktor-Faktor yang Mempengaruhinya. Rineka Cipta.

Sudjana, N. (2005). Penilaian Hasil Proses Belajar Mengajar. Remaja Rosdakarya.

Sugiyono. (2013). Metode Penelitian Pendidikan Pendekatan Kuantitatif, Kualitatif, dan R dan D. Alfabeta.

Sukaesih, S. (2011). Analisis Sikap Ilmiah dan Tanggapan Siswa terhadap Penerapan Model Pembelajaran Berbasis Praktikum, Jurnal Penelitian Pendidikan. Jurnal Penelitian Pendidikan, 28, 77-85.

Trianto. (2009). Mendesain Model Pembelajaran Inovatif - Progresif. Kencana.

Uno, H. B. (2006). Perencanaan Pembelajaran. Bumi Aksara.

Yanto, D.T.P.,Astrid, E.,Hidayat R., @ Islami S. (2019). Aanalisis Uji Kelayakan Trainer Kit Elektronika Daya. Teknik Elektro Dan Vokasional, 5, 121. 